\title{
Metode Kanguru Sebagai Pengganti Inkubator Untuk Bayi Berat Lahir Rendah
}

\author{
Rulina Suradi*, Piprim B Yanuarso **
}

\begin{abstract}
Penggunaan inkubator untuk merawat bayi berat lahir rendah (BBLR) memerlukan biaya yang tinggi. Akibat terbatasnya fasilitas inkubator, tidak jarang satu inkubator ditempati lebih dari satu bayi. Hal tersebut meningkatkan risiko tejadinya infeksi nosokomial di rumah sakit. Metode kanguru (MK) ditemukan pada tahun 1983 oleh dua orang ahli neonatologi dari Bogota, Colombia untuk mengatasi keterbatasan jumlah inkubator. Setelah dilakukan berbagai penelitian, ternyata MK tidak hanya sekedar menggantikan peran inkubator, namun juga memberi banyak keuntungan yang tidak bisa diberikan oleh inkubator. Metode kanguru mampu memenuhi kebutuhan asasi BBLR dengan menyediakan situasi dan kondisi yang mirip dengan rahim sehingga memberi peluang BBLR untuk beradaptasi dengan baik di dunia luar. Metode kanguru dapat meningkatkan hubungan emosi ibu-bayi, menstabilkan suhu tubuh, laju denyut jantung dan pernapasan bayi, meningkatkan pertumbuhan dan berat badan bayi dengan lebih baik, mengurangi stres pada ibu dan bayi, mengurangi lama menangis pada bayi, memperbaiki keadaan emosi ibu dan bayi, meningkatkan produksi ASI, menurunkan kejadian infeksi nosokomial, dan mempersingkat masa rawat di rumah sakit. Mengingat berbagai kelebihannya, diperlukan upaya yang lebih strategis untuk mempopulerkan metode yang sangat bermanfaat ini.
\end{abstract}

Kata kunci: BBLR - metode kangguru - inkubator

$\mathscr{A}$ ngka kejadian bayi berat lahir rendah (BBLR) di Indonesia masih relatif tinggi, yaitu sekitar 14\%. ${ }^{1}$ Di RS Dr. Cipto Mangunkusumo (RSCM) pada tahun 1996 Rohimi mendapatkan angka sebesar 13,8\%, ${ }^{2}$ sedangkan di RS M Djamil Padang Chundrayetti pada tahun 1998 mendapatkan angka sebesar $12,6 \%^{3}$

Di negara-negara berkembang termasuk Indonesia morbiditas dan mortalitas BBLR masih tinggi. Bayi berat lahir rendah merupakan penyumbang utama

*Staf Pengajar Subbagian Perinatologi Bagian Ilmu Kesehatan Anak FKUI-RSCM Jakarta (Dr. Rulina Suradi, SpA(K), ${ }^{* *}$ Peserta Program Dokter Spesialis Ilmu Kesehatan Anak FKUI/RSCM (Dr. Piprim B.Yanuarso)

Alamat korespondensi:

Dr. Rulina Suradi, SpA(K)

Jl. Salemba No. 6, Jakarta 10430, Indonesia.

Telpon: (021) 391 4126. Fax.: (021) 3914126. kematian neonatal. ${ }^{4,5}$ Di Subbagian Perinatologi IKA FKUI/RSCM selama tahun 1998 didapatkan angka kematian neonatal dini pada kelompok bayi dengan berat lahir <1000 g, 1000-1499 g, dan 1500-2499 g masing-masing sebesar $75 \%, 41,9 \%$, dan $6,6 \%{ }^{6}$ Penyebab utama kematian neonatal adalah asfiksia, hipotermia, dan infeksi. Selain kondisi yang buruk pada saat dilahirkan, kematian neonatal sering disebabkan oleh cara penanganan kasus yang tidak tepat. ${ }^{7,8}$

Di RSCM perawatan BBLR menggunakan fasilitas inkubator. Selain jumlahnya terbatas, perawatan dengan inkubator memerlukan biaya tinggi. Di samping itu angka kejadian infeksi nosokomial pada BBLR yang dirawat di rumah sakit cukup tinggi. ${ }^{9}$ Oleh karena itu diperlukan suatu metode praktis sebagai alternatif pengganti inkubator yang secara ekonomis cukup efisien dan efektif.

Kehangatan tubuh ibu ternyata merupakan sumber panas yang efektif untuk bayi yang lahir cukup bulan maupun BBLR. Hal ini terjadi bila terdapat kontak 
langsung antara kulit ibu dengan kulit bayi. Prinsip ini dikenal sebagai skin to skin contact atau metode kanguru (MK). ${ }^{10}$ Metode kanguru diperkenalkan pertama kali oleh Rey dan Martinez dua orang ahli neonatologi dari Bogota, Colombia Amerika Selatan pada tahun $1983^{11,12}$ Metode ini merupakan cara sederhana yang bermanfaat untuk meningkatkan kelangsungan hidup bayi baik sesaat maupun jangka lama, terutama BBLR dengan berat 1200-2000 g.

Dengan ditemukannya metode kanguru telah terjadi revolusi perawatan BBLR/ bayi kurang bulan (BKB). Metode ini bermanfaat bagi bayi prematur untuk membantu memulihkan akibat dari prematuritasnya dan menolong orangtua agar lebih percaya diri serta dapat berperan aktif dalam merawat bayinya. ${ }^{12}$ Metode kanguru berperan dalam perawatan bayi baru lahir secara manusiawi dan meningkatkan ikatan antara ibu dan bayi. ${ }^{13}$

Berdasarkan kenyataan tersebut maka metode kanguru perlu lebih dipopulerkan di Indonesia baik pada masyarakat pedesaan maupun perkotaan sehingga masalah angka kematian yang disebabkan oleh BBLR dapat dikurangi. Tujuan penulisan makalah ini adalah untuk mensosialisasikan penggunaan MK yang telah dapat diterima dengan baik oleh masyarakat pedesaan, ${ }^{8}$ namun belum populer di daerah perkotaan.

\section{Beberapa Permasalahan Bayi Berat Lahir Rendah}

Ada beberapa permasalahan BBLR yang akan dibahas adalah hipotermia, rendahnya daya tahan terhadap infeksi, enterokolitis nekrotikans, dan kebutuhan bayi berat lahir rendah.

\section{Hipotermia}

Salah satu ciri BBLR terutama BKB adalah mempunyai suhu yang tidak stabil dan cenderung hipotermia (suhu $<36,5^{\circ} \mathrm{C}$ ). Stres dingin dapat meningkatkan angka kematian dan menghambat pertumbuhan, sedangkan hipertermia dan suhu yang berfluktuasi dapat menimbulkan apneu. ${ }^{14}$ Suhu yang cenderung hipotermia disebabkan oleh produksi panas yang kurang dan kehilangan panas yang tinggi. Panas kurang diproduksi karena sirkulasi yang masih belum sempurna, respirasi masih lemah, konsumsi oksigen yang rendah, otot yang belum aktif, serta asupan makanan yang kurang. Kehilangan panas terjadi akibat dari permukaan tubuh yang relatif lebih luas dan lemak subkutan yang kurang, terutama lemak coklat (brown fat). Mekanisme kehilangan panas pada bayi dapat terjadi melalui konduksi, evaporasi, konveksi, dan radiasi. ${ }^{10}$

Hipotermia dapat mengakibatkan komplikasi jangka pendek berupa asidosis, hipoglikemia, dan gangguan pembekuan darah serta peningkatan risiko untuk distres pernapasan. Apabila berkepanjangan hipotermia dapat menyebabkan edema, sklerema, perdarahan hebat (terutama perdarahan paru), dan ikterus. $^{10}$

\section{Rendahnya daya tahan terhadap infeksi}

Bayi berat lahir rendah terutama BKB sangat rentan terhadap infeksi terutama infeksi nosokomial. ${ }^{9,14} \mathrm{Hal}$ ini disebabkan oleh kadar imunoglobulin serum yang rendah, aktivitas bakterisidal neutrofil dan efek sitotoksik limfosit juga masih rendah. ${ }^{14,15}$ Risiko untuk mendapat infeksi nosokomial meningkat apabila beberapa bayi dirawat bersama dalam satu inkubator -suatu hal yang masih terjadi di negara berkembang, bayi terlalu lama dirawat di rumah sakit, serta rasio perawat-pasien yang tidak seimbang. ${ }^{11,16,17}$

\section{Apneu pada bayi kurang bulan}

Kelainan ini terjadi akibat ketidakmatangan paru dan susunan saraf pusat. Apneu didefinisikan sebagai periode tak bernapas selama lebih dari 20 detik dan disertai bradikardia. Kelainan ini dapat ditemukan pada pemantauan yang teliti dan terus menerus. Semua bayi dengan masa kehamilan kurang dari 34 minggu harus secara rutin dan terus menerus dipantau sampai apneu itu hilang selama satu minggu. Pemberian teofilin dapat mengurangi kejadian apneu sekitar 60-90\%. ${ }^{14}$

\section{Enterokolitis nekrotikans}

Prematuritas merupakan faktor risiko terjadinya enterokolitis nekrotikans (EKN) pada neonatus. ${ }^{14,18}$ Kenaikan angka harapan hidup BKB menyebabkan kenaikan kejadian EKN. Kejadian EKN tertinggi pada bayi berat lahir < 1500 g. ${ }^{18}$ Etiologi penyakit ini multifaktor, yaitu faktor yang menyebabkan trauma hipoksik iskemik pada saluran cerna yang masih imatur, 
kolonisasi bakteri patogen, dan substrat protein berlebihan dalam lumen. ${ }^{14}$ Pemberian ASI dapat mencegah/mengurangi kejadian EKN karena ASI merupakan cairan normo-osmolar dan mengandung makrofag, limfosit, dan imunoglobulin yang mencegah kolonisasi bakteri patogen.

\section{Kebutuhan bayi berat lahir rendah}

Bayi berat lahir rendah, dalam hal ini bayi kurang bulan, kehilangan kesempatan untuk mempersiapkan diri hidup di luar uterus yang biasanya terjadi pada trimester ketiga. Makin muda usia gestasi, kemampuan beradaptasi makin berkurang. Agar mendapat peluang beradaptasi yang sama dengan bayi cukup bulan maka harus diberikan lingkungan dan kebutuhan yang sama dengan keadaan di dalam uterus. Monintja ${ }^{14}$ merumuskan kebutuhan tersebut sebagai berikut:

- Kebutuhan lingkungan fisik yang sesuai dengan pengaturan suhu, kelembaban udara, dan kebersihan lingkungan.

- Kebutuhan akan perfusi dan oksigenisasi jaringan yang baik agar fungsi metabolisme dan ekskretorik dapat berlangsung adekuat.

- Kebutuhan nutrisi yang sesuai dan adekuat yang menjamin tumbuh kembang optimal.

- Kebutuhan emosional dan sosial yang menunjang tumbuh kembang yang baik.

\section{Keuntungan Metode Kanguru}

Metode Kanguru adalah suatu metode perawatan BBLR yang diilhami oleh cara seekor kanguru merawat anaknya yang selalu lahir prematur. Bayi dalam posisi tegak (upright) atau prone (bila ibu berbaring), hanya memakai popok dan penutup kepala, didekap di antara kedua payudara ibu, bersentuhan kulit dengan kulit, dada dengan dada secara berkesinambungan. ${ }^{11,12}$

Berbagai penelitian mengenai metode kanguru telah dilakukan baik di negara berkembang maupun negara maju, dan didapatkan beberapa keuntungan menggunakan metode kanguru dibandingkan perawatan bayi secara tradisional (menggunakan inkubator). ${ }^{19-25}$ Meskipun demikian metode kanguru tidak dapat menggantikan namun dapat melengkapi, cara-cara mutakhir untuk memperbaiki pernapasan, namun sangat bermanfaat untuk membantu tercapai-nya stabilisasi pernapasan tersebut. ${ }^{12,14}$ Berikut ini akan diuraikan beberapa keuntungan menggunakan metode kanguru.

\section{Peningkatan hubungan emosi ibu-bayi}

Hubungan emosional ibu dengan bayi dimulai sejak kehamilan. Ikatan emosional yang disebut attachment atau bonding ini merupakan suatu proses hubungan bayi dengan orangtuanya. Kebutuhan bayi terhadap orangtua bersifat absolut, tetapi kebutuhan orangtua terhadap bayi bersifat relatif. Neonatus secara total sangat tergantung secara fisik dan emosional kepada yang merawatnya. ${ }^{13,14}$ Bayi dengan kontak yang dini dengan ibunya, lebih sedikit menangis, lebih sering tersenyum, dan lebih banyak memanfaatkan ASI daripada bayi yang kontak dengan ibunya terlambat atau tidak adekuat. ${ }^{26}$

Tessier dkk melaporkan bahwa ibu-ibu yang menggunakan metode kanguru merasa lebih percaya diri dalam merawat bayinya dibanding kelompok kontrol, dan apabila bayinya bermasalah sehingga perlu dirawat lebih lama di rumah sakit, perasaan khawatir akan keadaan anaknya lebih besar daripada kelompok kontrol. ${ }^{13}$ Di samping itu metode kanguru juga meningkatkan rasa kedekatan ibu dengan bayinya, ${ }^{27}$ mengurangi perasaan stres pada ibu sebagaimana pada bayi, serta membuat ibu dan bayi lebih tenang dan rileks. ${ }^{12}$ Semakin dini metode kanguru diterapkan hasilnya akan semakin baik. ${ }^{13}$

Di Colombia, ibu dari bayi yang lahir prematur sering menolak kehadiran bayinya karena dianggap tidak akan bertahan hidup. Akibatnya banyak BKB yang mati karena kurang diperhatikan dan terjadi sindrom gagal tumbuh. Dengan diterapkannya metode kanguru penolakan terhadap BKB menjadi berkurang dan sebaliknya ikatan emosi ibu-bayi meningkat. ${ }^{12}$

\section{Stabilisasi suhu tubuh}

Terdapat beberapa cara untuk menjaga suhu tubuh bayi tetap hangat yaitu dengan metode kanguru, ruangan hangat, botol yang dihangatkan, radiant warmer, tempat tidur berisi air yang dihangatkan, dan inkubator. Ditinjau dari segi efektivitas, keamanan dan higiene metode kanguru sama dengan inkubator tipe 3 yang paling canggih, namun dari segi biaya berbeda jauh. Metode kanguru tanpa biaya, kecuali cinta kasih orangtuanya. ${ }^{10}$

Suatu fenomena menarik tentang pengaturan suhu tubuh ibu yang menggunakan metode kanguru 
ditemukan oleh Ludington-Hoe, dkk. Didapatkan bahwa suhu ibu akan meningkat bila bayi mulai 'dingin' dan bila bayi telah 'hangat' maka suhu ibu menurun kembali. Hal ini tanpa disadari oleh ibu tersebut. Mereka menyebut fenomena ini sebagai maternalneonatal thermal synchrony. ${ }^{12}$

Christenson $\mathrm{K}$ dkk. melakukan penelitian terhadap 80 bayi yang berisiko rendah terhadap hipotermia di RS Pendidikan di Lusaka, Zambia. Secara acak bayi-bayi tersebut dibagi menjadi dua kelompok, kelompok I mendapat perawatan metode kanguru (skin-to-skin / STS) dibandingkan dengan kelompok II yang dirawat di inkubator dengan suhu $35^{\circ} \mathrm{C}$; kemudian suhu rektal diukur secara berkala. Hasilnya pada menit ke-240 didapatkan bahwa 90\% bayi kelompok I (metode kanguru) mencapai suhu normal $\left(36,5^{\circ} \mathrm{C}\right)$, sedangkan pada kelompok II (inkubator) hanya $60 \%{ }^{22}$

Pada metode kanguru tidak terjadi proses kehilangan panas baik melalui radiasi, konveksi, evaporasi, maupun konduksi; sedangkan dengan inkubator masih dapat terjadi proses kehilangan panas melalui radiasi yang dapat mencapai $>50 \% .{ }^{10}$ Penggunaan inkubator di negara berkembang memerlukan perhatian khusus terutama terhadap ketersediaan sumber listrik yang memadai, tenaga terlatih untuk supervisi, pemeliharaan, dan perbaikan alat, sterilisasi inkubator, dan jumlah inkubator. Seringkali dijumpai satu inkubator digunakan untuk lebih dari satu bayi karena jumlahnya terbatas, hal ini meningkatkan risiko terjadinya infeksi nosokomial. ${ }^{10,17}$

\section{Stabilisasi laju denyut jantung dan pernapasan}

Ludington-Hoe dkk. dalam penelitiannya menggunakan alat monitor kontinyu, menemukan bahwa selama perawatan menggunakan metode kanguru laju denyut jantung bayi relatif stabil dan konstan sekitar 140-160 kali per menit. Ketika bayi tidur saat perawatan metode kanguru, denyut jantung menjadi teratur. ${ }^{28}$

Penelitian lain dengan menggunakan pneumokardiogram, melakukan pengamatan terhadap pola respirasi dan denyut jantung sepanjang tiga interval di antara empat waktu penyusuan. ${ }^{29}$ Pada interval ke-1 bayi dirawat dalam boks, pada interval ke- 2 dengan metode kanguru, dan pada interval ke-3 dalam boks kembali. Pencatatan dilakukan setelah satu jam penyusuan.
Didapatkan bahwa laju napas dan denyut jantung selama metode kanguru lebih stabil dibanding perawatan dalam boks sebelum dan sesudah metode kanguru.

Mengenai pola pernapasan, Ludington-Hoe melaporkan bahwa selama metode kanguru frekuensi pernapasan bayi menjadi lebih dalam, kejadian apneu berkurang empat kali lipat, lama episode apneu, dan periodic breathing menjadi lebih singkat. ${ }^{28}$

\section{Pengaruh terhadap berat badan dan pertumbuhan}

Pertumbuhan secara keseluruhan bukan hanya berat badan, dapat meningkat selama perawatan dengan metode kanguru. Hal ini terjadi karena bayi dalam keadaan rileks, beristirahat dengan posisi yang menyenangkan, mirip dengan posisi dalam rahim, sehingga kegelisahan bayi berkurang dan tidur lebih lama. ${ }^{28}$ Pada keadaan demikian konsumsi oksigen dan kalori berada pada tingkat paling rendah, sehingga kalori yang ada digunakan untuk menaikkan berat badan. Selain itu peningkatan berat badan juga disebabkan oleh produksi ASI yang meningkat dan frekuensi menyusu yang lebih sering. ${ }^{28}$

\section{Pengaruh terhadap tingkah laku bayi}

Apabila kita mengetuk inkubator bayi maka reaksi yang ditunjukkan oleh bayi kurang bulan adalah sebagai berikut: frekuensi jantung meningkat, pernapasan menjadi lebih cepat, warna kulit berubah dari merah menjadi kebiruan, bayi menggerakkan semua anggota tubuhnya, kepalanya dipalingkan, mukanya menyeringai, dan dagunya diangkat. Respons tersebut dapat berlangsung selama dua menit. ${ }^{28} \mathrm{Hal}$ tersebut disebabkan pada bayi kurang bulan sistem saraf pusatnya belum matang sehingga kurang mampu menyeleksi atau mengurangi pengaruh lingkungan yang membuatnya bingung. Respons tersebut akan menghabiskan oksigen dan kalori yang diperlukan untuk pertumbuhannya. ${ }^{28}$

Pada bayi yang dirawat dengan metode kanguru, respons seperti di atas tidak terjadi. Apabila kita mengetuk punggung bayi perlahan-lahan atau membuat keributan di dekatnya, reaksi bayi hanya berupa kerutan wajah serta pergerakan jari tangan dan kaki yang berlangsung singkat. Selanjutnya bayi melanjutkan tidurnya dengan tenang tanpa terbangun. Bahkan di Colombia bayi dengan metode kanguru 
tidak semuanya menangis saat diambil darahnya. ${ }^{28}$

Anderson dkk. meneliti kadar kortisol saliva pada bayi yang dipisahkan dari ibunya dibandingkan dengan yang dirawat sendiri oleh ibunya. Secara teoritis kadar kortisol akan meningkat pada saat stres. Dilaporkan bahwa kadar kortisol saliva meningkat bermakna pada bayi yang dirawat terpisah dari ibunya. ${ }^{30}$

Pada perawatan metode kanguru bayi tidur dua kali lebih sering, serta lebih lama dan dalam. Hal ini penting agar bayi dapat 'waspada' (alert), sehingga bayi dapat melakukan kontak mata dengan ibunya dan memper-kuat ikatan ibu-bayi. Masa 'waspada' bayi berlangsung lebih lama saat perawatan metode kanguru daripada bayi yang dirawat terpisah dari ibu. ${ }^{28}$

Bayi yang dirawat di inkubator bisa menangis selama 2-3 menit sampai seseorang datang untuk merawatnya. Dengan metode kanguru jumlah tangisan dalam satu episode menurun bermakna bahkan banyak bayi yang tidak menangis sama sekali, atau jika menangis biasanya berlangsung selama satu menit. Tangisan yang terjadi selama metode kanguru biasanya terjadi pada saat bayi sedang lapar dan dapat segera diketahui oleh ibu dengan memberikan ASI. ${ }^{28}$

\section{Peningkatan produksi air susu ibu}

Air Susu Ibu pada kelompok metode kanguru jumlahnya lebih banyak secara bermakna dibanding kelompok kontrol. ${ }^{31}$ Peningkatan produksi ASI dapat terjadi dengan menguatnya ikatan emosi ibu-bayi sehingga terjadi letdown refleks yang penting bagi pengeluaran ASI. Di samping itu, stres yang biasa terjadi pada ibu-ibu yang bayinya dirawat di rumah sakit akan berkurang bila ibu diberi kesempatan mendekap bayinya dalam metode kanguru, ${ }^{31}$ hal ini berpengaruh positif terhadap produksi ASI.

\section{Pengaruh terhadap kejadian infeksi}

Tidak satu pun laporan tentang penggunaan metode kanguru yang menyatakan adanya peningkatan kejadian sepsis. ${ }^{32}$ Sloan dkk. bahkan melaporkan bahwa pada perawatan dengan inkubator lebih sering terjadi infeksi berat dibanding perawatan dengan metode kanguru. ${ }^{16} \mathrm{Hal}$ ini tampaknya disebabkan flora normal kulit ibu lebih 'aman' bagi bayi prematur yang mendapat ASI dibandingkan organisme yang resisten terhadap antibiotik yang terdapat di rumah sakit. ${ }^{32}$

\section{Berkurangnya hari rawat di Rumah Sakit}

Dengan diterapkannya metode kanguru hari rawat di rumah sakit menjadi jauh berkurang, meskipun jumlah kunjungan untuk kontrol meningkat. Hal ini menyebabkan penghematan biaya perawatan, berkurangnya beban perawat di rumah sakit serta menurunnya kejadian infeksi nosokomial. ${ }^{28}$

\section{Beberapa Kendala dan Upaya Penanggulangannya}

Faktor budaya, tingkat pengetahuan dan kebijakan pemerintah dapat berpengaruh terhadap pelaksanaan metode kanguru di masyarakat. Di negara dengan penggunaan ASI tidak populer maka metode kanguru akan sulit berkembang. ${ }^{29}$ Salah satu rahasia keberhasilan penerapan metode kanguru di Colombia adalah karena penggunaan ASI sudah merata di seluruh daerah.

Kebijakan pemerintah dalam menyebarluaskan informasi mengenai berbagai manfaat metode kanguru juga akan membantu penerapan metode ini di masyarakat. Di beberapa negara, media cetak dan elektronik turut berperan dalam mensosialisasikan metode ini kepada masyarakat. Demikian pula di Indonesia, penyebarluasan informasi secara terus menerus akan mampu mempopulerkan metode ini.

\section{Tatalaksana yang Dianjurkan}

Kriteria untuk mengikuti program perawatan bayi dengan metode kanguru antara lain ditetapkan oleh ISS world laboratory kangaroo mother program yaitu berat badan $\leq 2000 \mathrm{~g}$, tidak ada masalah patologis yang menyertai, refleks isap baik, koordinasi refleks isap dan menelan baik, perkembangan selama dalam inkubator baik, mempunyai orangtua yang menyetujui peraturan metode kanguru dan mematuhi jadual pertemuan, memiliki catatan medik yang lengkap serta memperoleh informed consent dari orangtua. ${ }^{29}$ Dalam pelaksanaannya perlu diperhatikan persiapan untuk ibu, bayi, posisi bayi, observasi bayi, cara pemberian ASI, serta kebersihan ibu dan bayi. Ilustrasi metode kanguru dapat dilihat pada Gambar 1. 


\section{Kesimpulan}

- Metode kanguru merupakan salah satu teknologi tepat guna yang sederhana, murah dan dapat digunakan ketika fasilitas untuk perawatan BBLR sangat terbatas.

- Metode kanguru ternyata tidak hanya sekedar menggantikan inkubator, namun juga memberi berbagai keuntungan yang tidak bisa diberikan oleh inkubator.

- Keuntungan menggunakan metode kanguru antara lain meningkatnya hubungan ibu-bayi, stabilisasi suhu tubuh bayi, stabilisasi laju denyut jantung dan pernapasan, pertumbuhan dan peningkatan berat badan yang lebih baik, mengurangi stres baik pada ibu maupun bayi, tidur bayi lebih lama, memperpanjang masa 'kewaspadaan' (alert) bayi, mengurangi lama menangis, memperbaiki keadaan emosi ibu dan bayi, meningkatkan produksi ASI, menurunkan kejadian infeksi, dan mempersingkat masa rawat di rumah sakit.

- Metode kanguru mampu memenuhi kebutuhan asasi bayi berat lahir rendah dengan menyediakan situasi dan kondisi yang mirip dengan rahim sehingga memberi peluang bagi BBLR untuk beradaptasi dengan baik di dunia luar.

- Diperlukan upaya yang lebih strategis untuk mempopulerkan metode yang sangat bermanfaat ini.

\section{Daftar Pustaka}

1. Departemen Kesehatan RI. Profil kesehatan Indonesia 1998. Jakarta: Pusat Data Kesehatan Jakarta,1998;217.

2. Rohimi S. Sebaran karakteristik bayi berat lahir rendah (pertumbuhan janin terhambat dan prematur). (Tesis). Jakarta: Fakultas Kedokteran Universitas Indonesia, 1997.
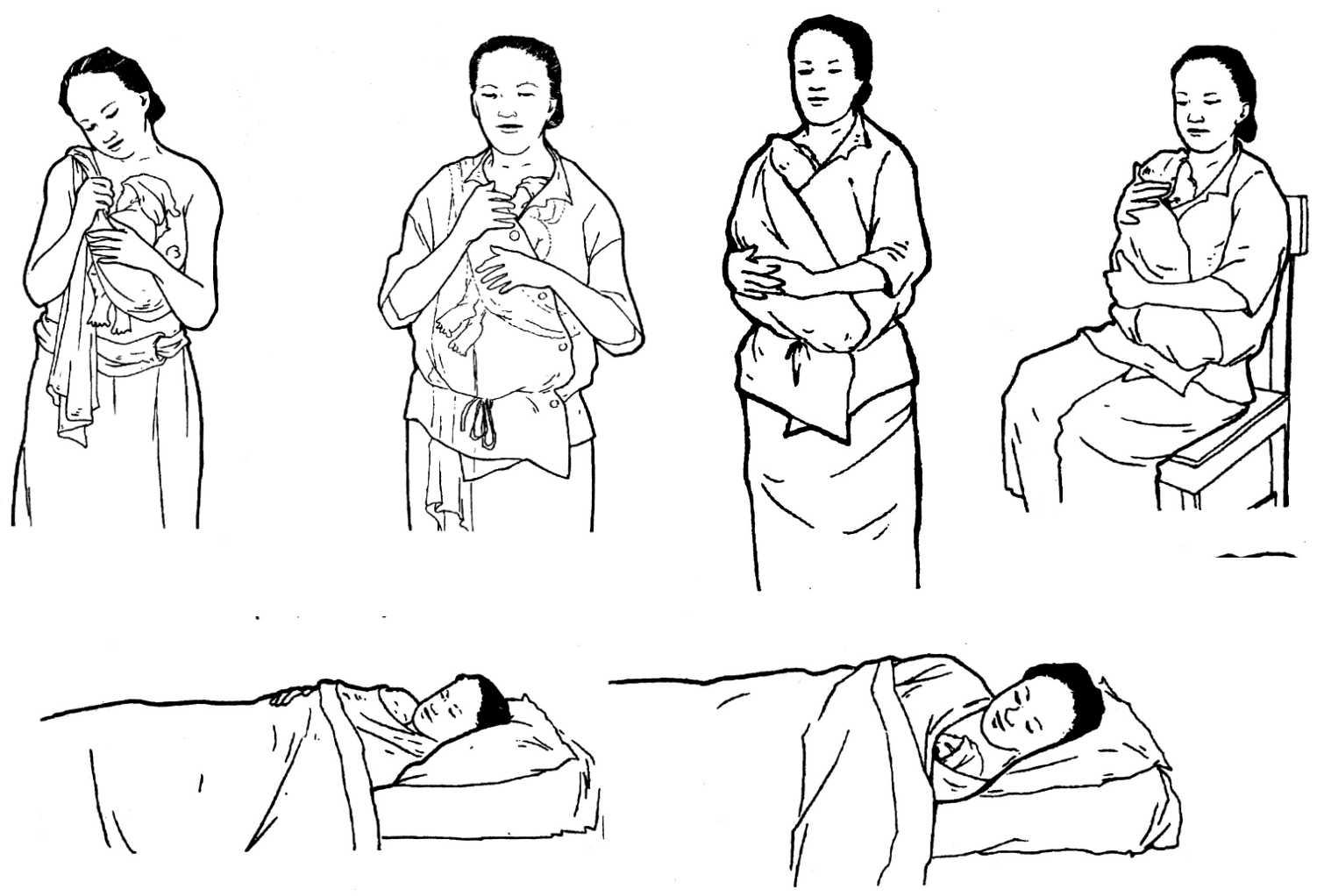

Gambar 1: Cara perawatan metode kanguru dan berbagai posisi dalam kegiatan sehari-hari. Dikutip dari Alisjahbana dkk., $1998^{33}$ 
3. Chundrayetti E. Kesakitan dan kematian neonatal dini pada bayi berat lahir rendah dan beberapa faktor yang mempengaruhinya di RSUP Dr M Djamil Padang. Dalam: Firmansyah A, Trihono PP, Oswari H, dkk., penyunting. Buku Abstrak KONIKA XI Jakarta. Jakarta: IDAI, 1999; 411.

4. Poerwosudarmo SS, Sunarya, Monintja HE. Perinatal mortality in Dr. Cipto Mangunkusumo General Hospital Jakarta. Pediatr Indones 1971; 11: 67-74.

5. Susilowati R. Kematian neonatal dini dalam hubungannya dengan berat lahir dan masa gestasi. (Tesis) Jakarta: Fakultas Kedokteran Universitas Indonesia, 1989.

6. Catatan rekam medik Subbagian Perinatologi IKA FKUI/RSCM (tidak dipublikasi).

7. Monintja HE. Kematian perinatal. Dalam: Wiknjosastro $\mathrm{H}$, penyunting. Ilmu kebidanan. Jakarta: Yayasan Bina Pustaka Sarwono Prawirohardjo, 1994; 785-90.

8. Suradi R, Chair I, Thaha RM. Acceptance of the kangaroo care method by mothers in rural area. Paediatr Indones 1998;38:215-23.

9. Kosim MS. Pola infeksi nosokomial di bangsal bayi baru lahir Bagian IKA FK Universitas Diponegoro/ RSUP Dr Kariadi Semarang. Dalam: Firmansyah A, Sastroasmoro S, Trihono PP, dkk., penyunting. Buku Naskah Lengkap KONIKA XI Jakarta. Jakarta: IDAI, 1999;h. 535-45.

10. World Health Organization. Thermal control of the newborn: a practical guide. WHO/FHE/MSM/93.2

11. Whitelaw A, Sleath K. Myth of the marsupial mother: home care of very low birth weight babies in Bogota, Colombia. Lancet 1985; I:1206-8.

12. Ludington-Hoe SM, Golant SK. Kangaroo care, the best you can do to help your preterm infant. New York: Bantam Books, 1993:3-30.

13. Tessier R, Cristo M, Velez S, Giron M, dkk. Kangaroo mother care and the bonding hypothesis. Pediatrics 1998;102:1-8.

14. Monintja HE. Beberapa aspek kebutuhan bayi kurang bulan. Dalam: Suradi R, Monintja HE, Amalia P, Kusumowardhani D, penyunting. Penanganan mutakhir bayi prematur. Naskah lengkap Pendidikan Kedokteran Berkelanjutan Bagian Ilmu Kesehatan Anak XXXVIII. Jakarta: Balai Penerbit FKUI,1997; h.11-43.

15. Kadri N. Mekanisme pertahanan tubuh pada bayi prematur. Dalam: Suradi R, Monintja HE, Amalia P, Kusumowardhani D, penyunting. Penanganan mutakhir bayi prematur. Naskah lengkap Pendidikan Kedokteran Berkelanjutan Bagian Ilmu Kesehatan Anak XXXVIII. Jakarta: Balai Penerbit FKUI,1997; h.115-30.

16. Sloan NL, Camacho LWL, Rojas EP, Stern C. Kangaroo mother method: randomised controlled trial of an alternative method of care for stabilised low-birthweight infants. Lancet 1994; 344:782-5.

17. Boedjang RF. Pengendalian infeksi nosokomial di ruang rawat neonatus. Dalam: Suradi R, Monintja HE, Amalia P, Kusumowardhani D, penyunting. Penanganan mutakhir bayi prematur. Naskah lengkap Pendidikan Kedokteran Berkelanjutan Bagian Ilmu Kesehatan Anak XXXVIII. Jakarta: Balai Penerbit FKUI,1997; h.151-6.

18. Markum AH, Monintja HE, Boedjang RF. Janin dan neonatus. Dalam: Markum AH, Ismael S, Alatas H, dkk, penyunting. Buku ajar ilmu kesehatan anak jilid 1 . Jakarta: FKUI, 1991; h.205-40.

19. Cattaneo A, Davanzo R, Uxa F, Tamburlini G. Recommendations for the implementation of kangaroo mother care for low birthweight infants. Acta Paediatr 1998; 87:440-5.

20. Bergman NJ, Jurisoo LA. The 'kangaroo-method' for treating low birth weight babies in a developing country. Tropical Doctor 1994;24:57-60.

21. Levin A. The mother-infant unit at Tallinn children's hospital, Estonia: a truly baby-friendly unit. Birth 1994;21:39-44.

22. Christensson K, Bhat GJ, Amadi BC, Eriksson B, Hojer B. Randomised study of skin-to-skin versus incubator care for rewarming low risk hypothermic neonates. The Lancet 1998;352:1115.

23. Charpak N, Ruiz-Pelaez JG, Figueroa Z, Charpak Y. Kangaroo mother versus traditional care for newborn infants $\leq 2000$ grams: a randomized, controlled trial. Pediatrics 1997;100:683-8.

24. Cattaneo A, Davanzo R, Worku B, dkk. Kangaroo mother care for low birthweight infants: a randomized controlled trial in different settings. Acta Paediatr 1998;87:976-85.

25. Charpak N, Ruiz-Pelaez JG, Charpak Y. Rey-Martinez kangaroo mother program: an alternatif way of caring for low birth weight infants? One year mortality in a two cohort study. Pediatrics 1994;94: 804-10.

26. De Chateau P, Winberg B. Longterm effect on mother infant behaviour of extra contact during the first hours post partum. II A follow-up at three months. Acta Paediatr Scand 1977;66:145-51.

27. Klaus MH, Kennell JH. Care of the parents. Dalam: Klaus MH, Fanaroff AA, penyunting. Care of the highrisk neonate. Edisi ke-4. Philadelphia: WB Saunders Company, 1993; h.189-211.

28. Ludington-Hoe SM, Golant SK. Kangaroo care, the best you can do to help your preterm infant. New York: Bantam Books, 1993; h.67-84.

29. Anderson GC. Touch and the kangaroo care method. Dalam: Field TM, penyunting. Touch in early development. New Jersey: Lawrence Erlbaum Associates, 1995; h.35-51.

30. Anderson GC, Wood CE, Chang HP. Self-regulatory mothering vs. nursery routine care postbirth: effect on salivary cortisol and interactions with gender, feeding, and smoking. Dipresentasikan pada International Workshop on Kangaroo Mother care II, Perancis 30 November - 4 Desember 1998.

31. Hurst NM, Valentine CJ, Renfro J, dkk. Skin-to-skin holding in the neonatal intensive care unit influences maternal milk volume. J Perinatol 1997;17:213-7.

32. Whitelaw A. Kangaroo baby care: just a nice experience or an important advance for preterm infants? Pediatrics 1990;85:604-5.

33. Alisjahbana A, Usman A, Irawaty S, Triyati A. Prevention of hypothermia of low birth infants using the kangaroo method. Paediatr Indones 1998;38:205-14. 